\title{
Characterisation of cell-wall-derived polypeptide antigens from different species of Mycobacterium
}

\author{
SUSAN BABU, N. K. JAIN, G. PRASAD, SUDHA BHATTACHARYA* and A. BHATTACHARYAT
}

\begin{abstract}
New Delhi Tuberculosis Centre, New Delhi-110 002, * School of Environmental Sciences, Jawaharlal Nehru University, New Delhi-110 067, and TSchool of Life Sciences, Jawaharlal Nehru University, New Delhi-110 067. India
\end{abstract}

\begin{abstract}
Summary. Cell walls from different species of Mycobacterium were purified on a sucrose step gradient. The components derived from these preparations were characterised by sodium dodecyl sulphate-polyacrylamide gel electrophoresis, followed by staining or by Western blotting. Surface-exposed polypeptide molecules were also identified by biotinylation. Many protein and glycoprotein molecules were identified in the cell walls. Some of these molecules were immunogenic in man and experimental animals and showed wide variability from species to species. The data suggest that these molecules could be of significance in the diagnosis and pathophysiology of mycobacterial diseases.
\end{abstract}

\section{Introduction}

In addition to Mycobacterium tuberculosis, other species of Mycobacterium cause tuberculosis-like disease in man. This has led to intensive studies of methods to identify and define mycobacterial species in order to develop more effective tools for the diagnosis and prevention of tuberculosis and other mycobacterial diseases.

At present, identification of non-tuberculous mycobacteria is based on colony morphology, pigment production, growth rate, temperature preference, biochemical tests and serotyping. ${ }^{1}$ These tests may give ambiguous results because of phenotypic variations among different strains of the same species. ${ }^{2,3}$ Taxonomic studies in mycobacteria have also been performed with the help of serological techniques, including immunodiffusion and immuno-electrophoresis, ${ }^{4}{ }^{5}$ but cross-reactive antigens present in different mycobacterial species make analysis difficult.

Among the species-specific antigens that have been identified are: the phenolic glycolipid of $M$. leprae, ${ }^{6}$ antigen 60 of $B C G^{7}$ and antigen 5 of $M$. tuberculosis. ${ }^{8}$ There is still considerable need to identify and characterise more such antigens. Cellwall antigens, especially polypeptide antigens, have not been characterised in mycobacteria.

Received 16 Oct. 1989 ; revised version accepted 7 Feb. 1990

† Correspondence should be sent to: Dr A. Bhattacharya, School of Life Sciences, Jawaharlal Nehru University, New Delhi110067 , India.
Since the cell wall is involved in interaction with the host, these molecules probably have a role in pathogenesis. In this report, we describe the preliminary characterisation of antigens derived from cell walls of a few, selected species of Mycobacterium.

\section{Materials and methods}

\section{Mycobacteria}

Species used in this study were: $M$. asiaticum TMC 803, $M$. smegmatis TMC 1548, M. gordonae TMC 1324, $M$. bovis BCG US 1037, $M$. fortuitum ND-125 and $M$. tuberculosis H 37 Ra L-3-TMC-201.

\section{Sera}

Sera from patients were obtained from the out-door department of the New Delhi Tuberculosis Centre, New Delhi, India. Rabbit anti-M. tuberculosis (H 37 Ra strain) serum was a kind gift from Mr U. Kumar and Dr Saxena, School of Life Sciences, Jawaharlal Nehru University, New Delhi.

\section{Preparation of mycobacterial antigens}

Mycobacteria were grown in Middlebrook 7H9 medium and lysed as described before. ${ }^{9}$ Briefly, the cells were harvested by centrifugation at $7000 \mathrm{~g}$ for $20 \mathrm{~min}$ at $4{ }^{\circ} \mathrm{C}$ and were washed with phosphate-buffered saline (PBS; $10 \mathrm{~mm}$ sodium phosphate, $0 \cdot 14 \mathrm{M} \mathrm{NaCl}, \mathrm{pH} 7 \cdot 2$ ). The washed cells were resuspended to a concentration of 
$250 \mathrm{mg}$ (wet weight) $/ \mathrm{ml}$ in Tris-buffered saline $(110 \mathrm{~mm}$ Tris- $\mathrm{HCl}, \mathrm{pH} 7.5,150 \mathrm{mM} \mathrm{NaCl}$ ) containing $2.0 \mathrm{mM}$ phenylmethylsulphonylfluoride (Sigma). The cell suspension was frozen, and then thawed at $37^{\circ} \mathrm{C}$. After 10 cycles of freezing and thawing, the broken cells were further disintegrated by ultrasonication for $10 \mathrm{~min}$ at $4^{\circ} \mathrm{C}$. The cell lysate was stored frozen in separate small volumes at $-70^{\circ} \mathrm{C}$.

\section{Preparation of cell walls}

Cell lysate was layered on to a discontinuous sucrose gradient $(25 \%, 33 \%, 45 \% \mathrm{w} / \mathrm{v} ; 2.0 \mathrm{ml}$ each) and then centrifuged at $1230 \mathrm{~g}$ for $10 \mathrm{~min}$ at $4^{\circ} \mathrm{C}$. The fraction containing the cell wall was collected from the interphase of the 33 and $45 \%$ sucrose layers. This fraction was examined microscopically and was found to be essentially free of unbroken whole cells. Plasma-membrane components were removed by washing with the non-ionic detergent, Triton X-114 (Sigma) $1.0 \%$ w/v at $4^{\circ} \mathrm{C}$. Cellwall components were dissolved in sodium dodecyl sulphate-polyacrylamide gel electrophoresis (SDSPAGE) sample buffer at $100^{\circ} \mathrm{C}$ for $5 \mathrm{~min}$.

\section{Biotinylation of cells}

Biotinylation was performed as described by Heitzmann and Richards. ${ }^{10}$ Briefly, mycobacterial cells were harvested by centrifugation and then washed twice with $0.1 \mathrm{M}$ sodium bicarbonate; $20 \mathrm{mg}$ (wet weight) of cells were suspended in $1.0 \mathrm{ml}$ of $0.1 \mathrm{M}$ sodium bicarbonate. To $500 \mu 1$ of suspension, $0.1 \mathrm{ml}$ of biotinyl- $N$-hydroxysuccinimide ester $(20 \mathrm{mg} / \mathrm{ml}$ in dimethylformamide) was added and incubated at room temperature with shaking. After incubation the cells were washed twice with $0 \cdot 1 \mathrm{M}$ sodium bicarbonate and then suspended in SDS-PAGE buffer.

\section{$S D S-P A G E$}

Unless otherwise mentioned, antigens were separated by electrophoresis on discontinuous $12 \%$ polyacrylamide gels $^{11}$ and stained with Coomassie Blue R 250. Molecular weights were determined by comparison with standard mol. wt markers (Sigma).

\section{Solubility test}

The solubility of cell-wall-derived components was determined by incubation with SDS-PAGE sample buffer with and without 2-mercaptoethanol at different temperatures. After $10 \mathrm{~min}$, the suspension was centrifuged and the supernate was used for electrophoresis.

\section{Enzyme treatment}

Extracted cell-wall pellets ( $500 \mu \mathrm{g}$ of protein) were resuspended in $200 \mu \mathrm{l}$ of $10 \mathrm{~mm}$ Tris- $\mathrm{HCl}, \mathrm{pH} 8 \cdot 0$, containing proteinase $\mathrm{K} 125 \mu \mathrm{g} / \mathrm{ml}$. Digestion was al- lowed to proceed for $1 \mathrm{~h}$ at $37^{\circ} \mathrm{C}$. The cell-wall pellet was collected by centrifugation and resuspended in SDSPAGE sample buffer.

The cell wall was also digested with lysozyme (Worthington, USA) $2 \mathrm{mg} / \mathrm{ml}$ for $1 \mathrm{~h}$ at $37^{\circ} \mathrm{C}$ and processed as for digestion with proteinase $\mathbf{K}$.

\section{Western blot analysis}

After electrophoresis, the separated proteins were transferred electrophoretically to a nitrocellulose membrane in $\mathrm{pH} 8.3$ buffer containing $25 \mathrm{mM}$ Tris- $\mathrm{HCl}$, $192 \mathrm{~mm}$ glycine, SDS $0 \cdot 1 \% \mathrm{w} / \mathrm{v}$, methanol $20 \% \mathrm{v} / \mathrm{v} .^{12}$ Antigens were identified with the help of appropriate antibodies and protein A-peroxidase conjugate (Bio-Rad, USA).

\section{Lectin blot}

A concanavalin A (Con A) blot was performed as described by Kigimoto-Ochiai et al. ${ }^{13}$ After transfer, the nitrocellulose membrane was incubated with Con $\mathrm{A}$ in

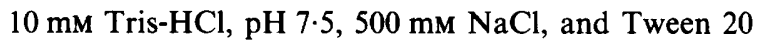
$0.05 \% \mathrm{w} / \mathrm{v}$, containing $1.0 \mathrm{mM} \mathrm{Ca}^{++}$and $1.0 \mathrm{mM} \mathrm{Mn}^{++}$ for $1 \mathrm{~h}$. The amount of Con $\mathrm{A}$ bound was determined by incubation with horseradish peroxidase (Sigma).

\section{Protein assay}

Protein concentrations were determined with bicinchoninic acid reagent (Pierce, USA). Assays were done in 96-well microtitration plates; $50 \mu$ l of the reagent was added and colour was estimated at $540 \mathrm{~nm}$.

\section{Results}

\section{Preparation of mycobacterial cell wall}

During cell lysis, some cells were observed to maintain their integrity. A sucrose step gradient was used to fractionate cell lysates and to allow separation of cell envelope from whole cells. The fraction that was insoluble in non-ionic detergent was considered to be derived from the cell wall. The SDS-PAGE pattern of a few species is presented in fig. $1 \mathrm{~A}$, which shows a number of bands that could be either polypeptides or glycopolypeptides.

\section{Characterisation of polypeptides derived from cell wall}

To determine which of these polypeptides were glycoconjugates, lectin blots were allowed to react with Con $\mathrm{A}$ and the amount of lectin bound was identified by their ability to bind horseradish peroxidase (fig. 1B). Several bands of $150,80,67$, 57 and $39.5 \mathrm{Kda}$ were observed. There was a strong 
A

B

$\begin{array}{lll}1 & 2 & 3\end{array}$

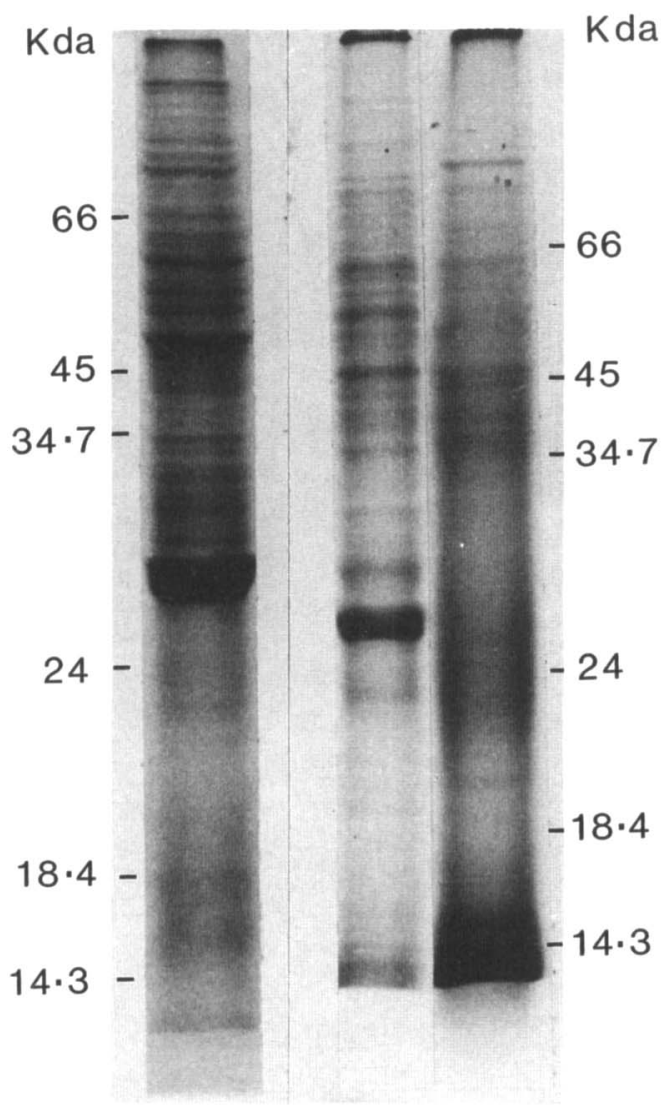

C
$4 \quad 5 \quad 6$

$\mathrm{Kda}$

$-180$

$-116$

$-84$

$-58$

$-48 \cdot 5$

$-36 \cdot 5$

$-26 \cdot 6$

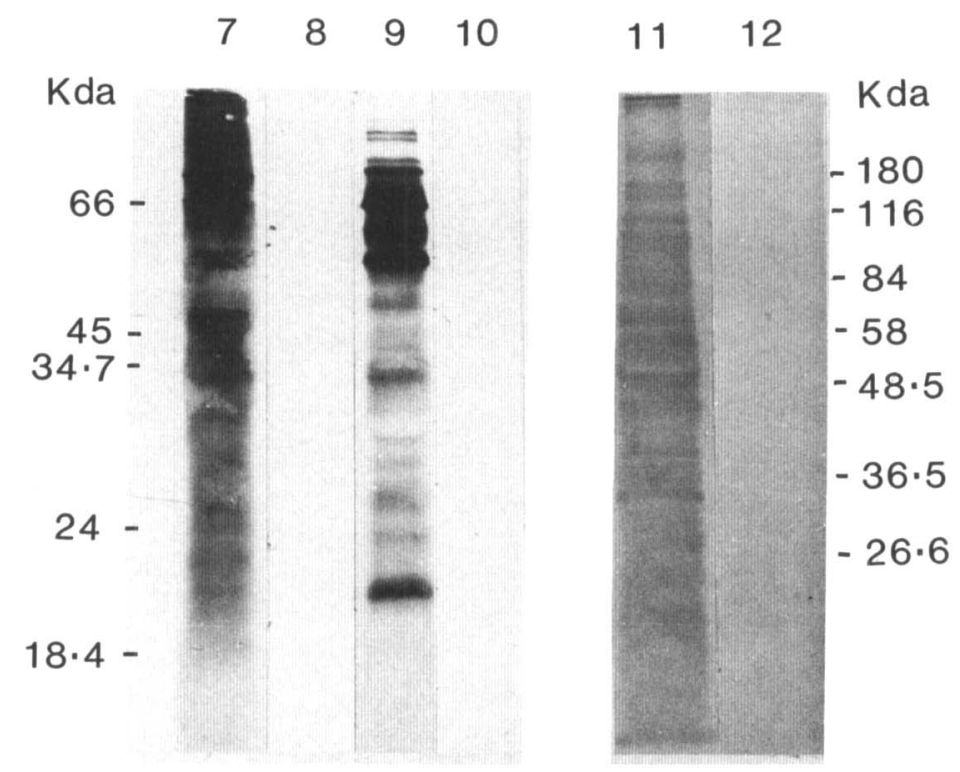

Fig. 1. Characterisation of cell-wall components by SDS-PAGE. Purified cell wall components were analysed on a discontinuous polyacrylamide $12 \%$ gel and stained with Coomassie Blue (A). After separation, the components were transferred electrophoretically to nitrocellulose membranes and probed with lectin Con A (B); the cell surface molecules were also labelled by biotinylation (C). Lanes 1, 4, 7, 8-M. gordonae; lanes 2, 5, 9, 10-M. fortuitum; lanes 3, 6, 11, 12-M. asiaticum; lanes 8, 10, 12-non-biotinylated controls. 
straining material at very high mol. wt in some species.

Periodic acid schiff's (PAS) staining failed to detect any glycoconjugates which did not bind Con A.

To identify which of the cell-wall components were exposed at the cell surface, intact mycobacterial cells were biotinylated and the results were compared with the convention gel pattern purified on the sucrose gradient. Fig. 1C shows that several bands were common to the two preparations, but some were different, suggesting that there may not be exposed reactive groups on these molecules.

\section{Changes in the molecular profile during growth}

Cell-wall profiles of mycobacteria harvested in early log phase, middle log phase and late log phase were identical.

\section{Solubility of cell wall components}

The nature of the interaction between cell-wall components and the insoluble matrix was investigated by checking solubility under different conditions (fig. 2). SDS and high temperature were required to solubilise cell wall components; at low temperature there was less soluble material. 2Mercaptoethanol was not essential for solubilising cell wall components.

\section{Enzyme treatment}

The electrophoretic pattern observed after proteolytic digestion showed that most bands were digested by the enzyme except for two bands of 31 and $28 \mathrm{Kda}$.

There was no difference in electrophoretic pattern of undigested samples and those treated with lysozyme.

\section{Antigenicity of cell-wall-derived components}

The immune human sera recognised two polypeptides of 28 and $31 \mathrm{Kda}$ from BCG-derived cellwall components (fig. 3C, lane 9). The polyclonal rabbit antiserum recognised these two antigens as well as other antigens of 56 and $18 \mathrm{Kda}$ (fig. $3 \mathrm{~A}$, lane 3 ). However, only one antigen ( $28 \mathrm{Kda})$ could be demonstrated in $M$. asiaticum preparations with immune human serum. Unlike the result with BCG, polyclonal antibody recognised a different antigen of $24 \mathrm{Kda}$ in $M$. asiaticum (fig. 3C, lane 7).

\section{Comparison of different mycobacterial species}

The feasibility of using the SDS-PAGE pattern of cell-wall polypeptides as markers of different species was investigated (fig. 4). Most bands were found to be different among different species. However, one common band of $47 \mathrm{Kda}$ was observed in all mycobacteria tested.

\section{Discussion}

Suitable methods are needed for the diagnosis of mycobacterial disease and for the development of newer immuno-prophylactic methods as existing methods are inadequate. Many approaches have been used to develop markers for the differentiation of mycobacterial species. However, approaches based on the detection of polypeptide antigens in

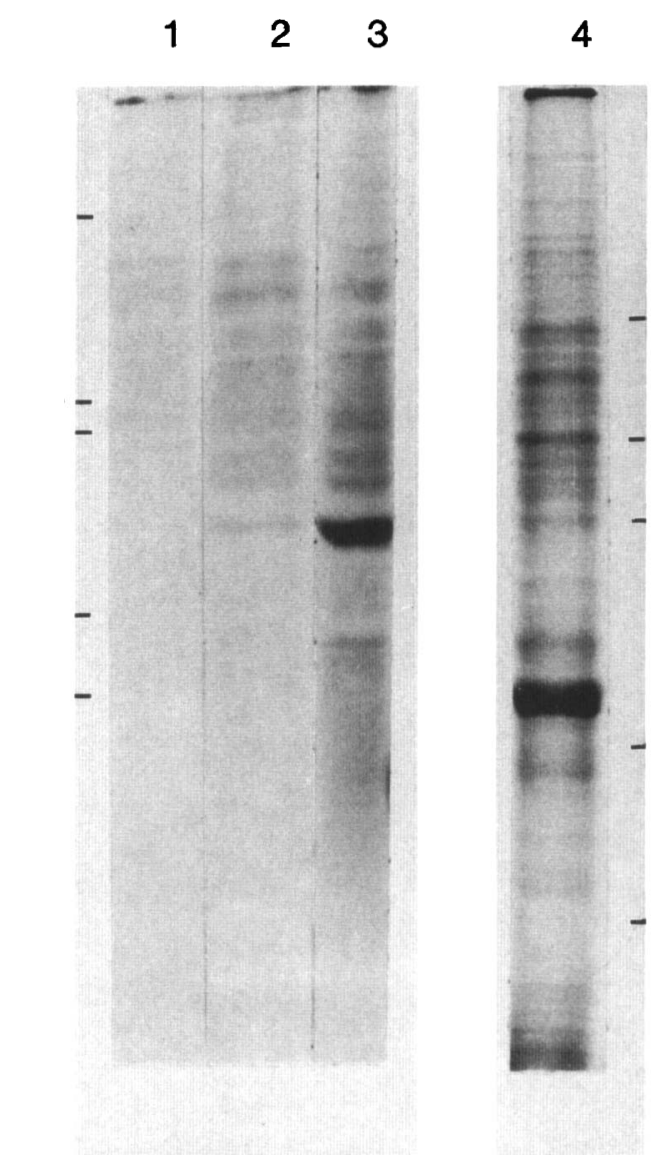

Fig. 2. Solubility of cell-wall fraction. Purified cell-wall fraction was incubated in SDS-PAGE sample buffer with (lanes 1,2 and 4) and without (lane 3) 2-mercaptoethanol at: $25^{\circ} \mathrm{C}$ (lane 1); $60^{\circ} \mathrm{C}$ (lane 2); $100^{\circ} \mathrm{C}$ (lanes 3 and 4 ). 


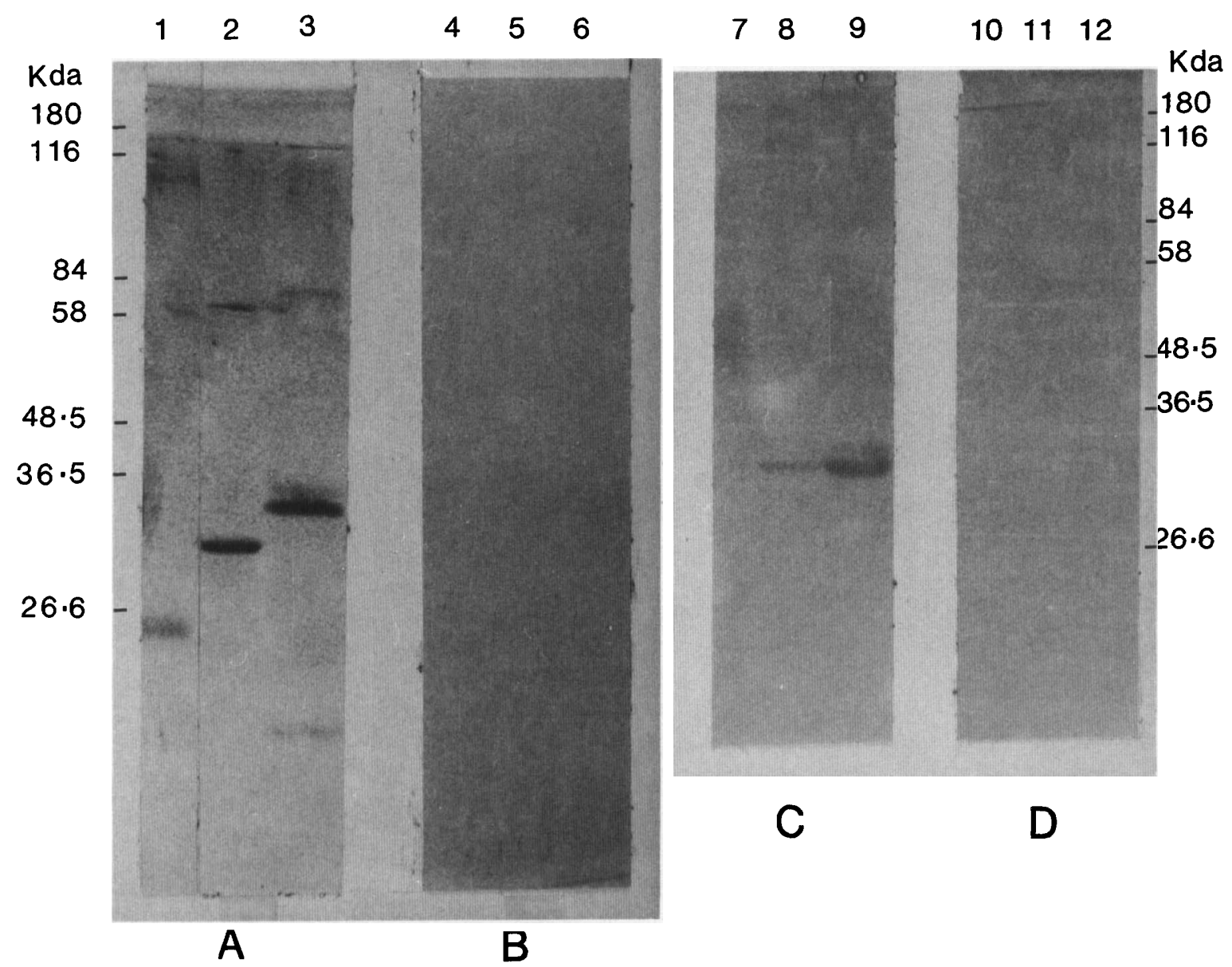

Fig. 3. Western blot analysis of cell-wall-derived components. The separated proteins were probed with (A) rabbit, anti $M$. tuberculosis-H $37 \mathrm{Ra}$; (B) pre-immune rabbit serum; (C) pooled immune serum from tuberculosis patients; (D) normal human serum. Lanes 1, 4, 7, 10-M. asiaticum; lanes 2, 5, 8, 11-M. fortuitum; lanes 3, 6, 9, 12-M. bovis BCG.

the soluble fraction of the cell lysates ${ }^{8,14}$ or identification of non-protein antigens in the cell wall components ${ }^{15}$ have been unsuccessful.

No systematic search has been made for characteristic polypeptides, including glycoproteins derived from cell wall. These molecules may be significant in pathogenesis because of their ability to interact with the host cells. In this study, we have attempted to purify and partially characterise these molecules. Since whole cells and membrane components could interfere with our analysis, purification was devised in such a way as to eliminate these fractions. The fraction that was insoluble in nonionic detergent was found to be soluble in SDSPAGE sample buffer only at high temperature, and 2-mercaptoethanol was not needed, suggesting that these molecules are not anchored to the cell-wall peptidoglycan layer through disulphide linkage.
The molecules were soluble only in SDS; in the absence of SDS they tended to precipitate out. Moreover, in the absence of SDS, no blotting was observed during electrophoretic transfer from gel to nitrocellulose (data not shown).

Biotinylation of whole cells mainly modifies cellsurface molecules. Differences between the biotinylated and Coomassie Blue patterns suggest that not all cell-wall-derived polypeptides are exposed on the surface. It is possible that the number of biotinyl residues attached to a polypeptide is not directly proportional to the concentration in the cell wall because some molecules may be labelled to high specific activity despite low concentration in the cell wall.

The surface molecules of bacteria are mostly glycoproteins, but in the case of mycobacteria these molecules are either glycolipids or complex carbo- 


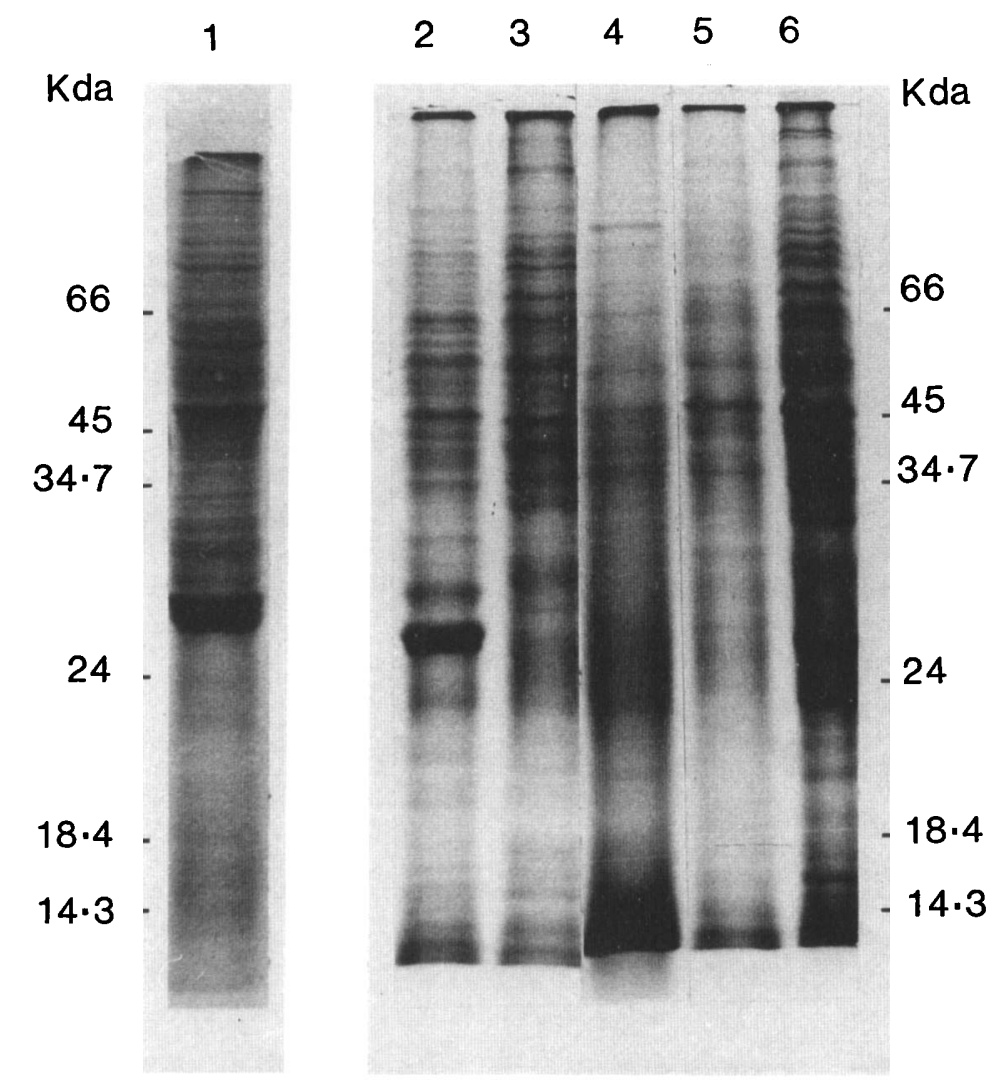

Fig. 4. SDS-PAGE profile of cell-wall-derived components of different species of Mycobacterium. Lane $1 \mathrm{M}$. gordonae; lane $2 \mathrm{M}$. fortuitum; lane $3 \mathrm{M}$. bovis $\mathrm{BCG}$; lane $4 \mathrm{M}$. asiaticum; lane $5 \mathrm{M}$. tuberculosis $\mathrm{H}_{37} \mathrm{Ra}$; lane $6 \mathrm{M}$. smegmatis.

hydrates. ${ }^{16,17}$ Most molecules observed by SDSPAGE appeared to be either polypeptides or glycopolypeptides for the following reasons: (a) normally, complex sugars or glycolipids show diffuse and broad bands in SDS-PAGE and we observed sharp bands; (b) most were susceptible to proteolytic digestion; (c) many bands also reacted with Con A; and (d) these molecules could be labelled with the biotin reagent.

Not all glycoprotein bands bound Con A, indicating that they do not all contain mannose or glucose. Failure to stain the glycoproteins with PAS may indicate that the amount of components in individual bands may be insufficient. Dense staining of diffuse material in $\boldsymbol{M}$. asiaticum may be due to complex carbohydrates or glycolipids as these molecules are neither susceptible to biotinylation nor stain with Coomassie Blue.

We observed two bands of 31 and $28 \mathrm{Kda}$ which were resistant to proteinase $\mathrm{K}$. These molecules may be buried in the cell wall or may be degraded molecules partially exposed to the enzyme. The lack of any effect of lysozyme on solubility indicates that these molecules are not attached to the cell wall through the peptidoglycan layer.

Some of these molecules stimulate an immune response in patients and in animals. The $28-\mathrm{Kda}$ band reacted only with patient serum, and not with polyclonal antibodies raised in rabbits. This difference suggests that different epitopes may be presented in different hosts. Further work is needed to investigate possible correlations between antibody response to cell-wall components and pathophysiology of mycobacterial disease.

Comparison of a few selected species of $\mathrm{Myco}$ bacterium by means of SDS-PAGE profiles revealed major differences, although a $47-\mathrm{Kda}$ band was found in all mycobacteria. To investigate the feasibility of using cell-wall-derived SDS-PAGE profiles for taxonomic and diagnostic purposes, other species of Mycobacterium and different strains of the same species must be studied.

This work was partly supported by a grant from the Tuberculosis Association of India. 


\section{REFERENCES}

1. Schaefer WB. Serological identification of atypical mycobacteria. In: Bergan T, Norris J R (eds) Methods in microbiology. London, Academic Press. 1979 ; 13 : 323343.

2. Stanford JL, Grange JM. The meaning and structure of species as applied to mycobacteria. Tubercle 1974; 55: 141-152.

3. Wayne LG. Mycobacterial taxonomy: a search for discontinuities. Ann Microbiol (Paris) 1978; 129 : 13-27.

4. Daniel TM, Good RC, Janicki BW. Immuno-electrophoresis of Mycobacterium tuberculosis antigens. Comparative analysis of cell extract and culture filtrate antigens. Am Rev Resp Dis 1975; 112: 639-644.

5. Stanford JL. Immunodiffusion analysis: a rational basis for the taxonomy of mycobacteria. Ann Soc Belg Med Trop 1973; 53: 321-330.

6. Hunter SW, Brennan PJ. A novel phenolic glycolipid from Mycobacterium leprae possibly involved in immunogenicity and pathogenicity. J Bacteriol 1981 ; 147 : 728 735.

7. Closs O, Harboe M, Axelsen NH, Bunch-Christenson K, Magnusson M. The antigens of Mycobacterium bovis, stain BCG studied by crossed immunoelectrophoresis: a reference system. Scand J Immunol 1980; 12: 249263.

8. Daniel TM, Anderson PA. The isolation by immunoabsorbent affinity chromatography and physiochemical characterization of Mycobacterium tuberculosis antigen 5. Am Rev Resp Dis 1978; 117: 533-539.

9. Bhattacharya A, Ranadive SN, Kale M, Bhattacharya S.
Antibody-based Enzyme-linked Immunosorbent Assay for determination of immune complexes in clinical tuberculosis. Am Rev Resp Dis 1986; 134: 205-209.

10. Heitzmann H, Richards FM. Use of the avidin-biotin complex for specific staining of biological membranes in electron microscopy. Proc Natl Acad Sci USA 1974; 71 : $3537-3541$.

11. Laemmli UK. Cleavage of structural proteins during the assembly of the head of bacteriophage T4. Nature 1970; 227: 680-685.

12. Bartles JR, Hubbard AL. ${ }^{125}$ I-Wheat-germ agglutinin blotting increased sensitivity with polyvinyl-pyrrolidone quenching and periodate oxidation reductive phenylamination. Anal Biochem $1984 ; 140$ : 284-292.

13. Kijimoto-Ochiai S, Katagiri TU, Ochiai H. Analysis of Nlinked oligosaccharide chains of glycoproteins on nitrocellulose sheets using lectin-peroxidase reagents. Anal Biochem 1985; 147 : 222-229.

14. Daniel TM, Ferguson LE. Purification and characterization of two proteins from culture filtrates of Mycobacterium tuberculosis $\mathrm{H}_{37} \mathrm{Ra}$ strain. Infect Immun 1970; 1 : 164168.

15. Riviere M, Fournie JJ, Puzo G. A novel mannose containing phenolic glycolipid from Mycobacterium kansasii. J Biol Chem 1987; 262 : 14879-14884.

16. Acharya PVN, Goldmann DS. Chemical composition of the cell wall of the $\mathrm{H}_{37} \mathrm{Ra}$ strain of Mycobacterium tuberculosis. J Bacteriol 1970; 102: 733-739.

17. Azuma I, Ribi E, Meyer T, Zbar B. Biologically active components from mycobacterial cell wall. I. Isolation and composition of cell wall skeleton and component $\mathrm{P}_{3}$. J Natl Cancer Inst 1974; 52: 95-101. 
